\title{
Optimization Two Chemical Reaction Processes for Producing Biodiesel from Waste Oil
}

\section{Azhari Muhammad Syam*, Heri Irmada Sriwindari Ginting and Zainuddin Ginting}

Department of Chemical Engineering, Universitas Malikussaleh Lhokseumawe, Indonesia

*Corresponding Author: Azhari Muhammad Syam, Department of Chemical Engineering, Universitas Malikussaleh Lhokseumawe, Indonesia.
Received: February 28, 2020

Published: March 18, 2020

(C) All rights are reserved by Azhari

Muhammad Syam., et al.

\begin{abstract}
This paper reveals on the production of biodiesel from waste oil. The production scenario was carried out via esterification and transesterification. As the feedstock of transesterification, the waste oil should be in a good quality with a low content of trash compounds such as free fatty acid (FFA). This study was initiated by an acid treatment for reducing FFA content of waste oil. Thus, it was followed by transesterification under a strong alkali as catalyst at $60^{\circ} \mathrm{C}$ of reaction temperature. A molar ratio of methanol to oil was determined in excess to maintain the reaction equilibrium. To optimize the applied parameters in this study, response surface methodology (RSM) or design expert application was used. The results showed that the esterification was successfully to minimize FFA of waste oil less than $1.0 \%$, and transesterification was able to produce a maximum quantity of biodiesel at around $85 \%$.
\end{abstract}

Keywords: Biodiesel; Waste Oil; Optimization

\section{Introduction}

The fossil fuel depletion, the demand of fuel and the uncertainty of resource availability is a serious trigger to search for alternative fuel to replace the fossil fuel [1]. As fuel alternative, biodiesel takes a significant role in reducing accumulation of green house gas in atmosphere and keep a benign environmental [2]. Furthermore, Jung., et al. [3] revealed that during the few years ago, environmental pollution and shortage of fossil fuels have been an interest topic, and research on alternative fuels have received much attention. Biodiesel is considered as a promising alternative to diesel fuel.

The raw material costs and limited availability of vegetable feedstock are always critical issues for the biodiesel production. The high costs of green feedstock, which could be up to more than fifty percentage of the total manufacturing cost, has led to the production costs of biodiesel becoming approximately almost two time higher than that for diesel [4]. Besides that, because of the lack of conventional resources for fuels, researchers started to explore alternative resources to meet the energy demand for present and future. The challenge and implication on environmental has created a wide attention to find notable alternative fuels [5]. Other researchers reported that the nowadays serious problem for biodiesel production is the high price of green feedstock which leads to a highly impact on the biodiesel price. Using of waste based feedstock is carried out to anticipate such situation [2].

In terms of application, many reports have been made about using waste oil biodiesel instead of conventional diesel which is able to decrease harmful exhaust emission with equivalent engine performance. The results concluded that waste oil biodiesel is advantageous in reducing carbon monoxide (CO), hydrocarbon (HC), and smoke emission especially with high injection pressure [6]. In another study, Anderson., et al. [7] revealed that the best behaviour considering fuel consumption, power, and emission was obtained for blending formula B20. 
In line with Indonesian government program, particularly regarding use of palm oil as fuel, has applied since few years ago. The objective of present work is to produce biodiesel from waste oil in supporting the program in general. In this work, both esterification and transesterification are optimized and various interaction parameters are also investigated using response surface methodology (RSM).

\section{Materials and Methods}

\section{Materials}

The waste oil was collected from the local restaurants. The initial content of waste oil FFA was $35.75 \%$ w/w. The chemicals applied were methanol (System), sulphuric acid (Fisher Scientific), potassium hydroxide (System), and phosphoric acid (Fisher Scientific). Instead of glass wares, other materials were used such as three necks flask, graham condenser, thermometer, and hot plate $\mathrm{c} / \mathrm{w}$ stirrer.

\section{Methods}

\section{Esterification}

Once the waste oil has a high FFA content, it should be treated by acid pre-treatment. Firstly, an amount of waste oil was scaled, thus it was heated at certified temperature. A strong acid was applied as catalyst. The reaction took place about 90 minutes. The final evaluation of FFA percentage was performed by titration method.

\section{Transesterification}

The treated waste oil was used as feedstock for transesterification. The oil was heated at certified degree cent ridge after its amount was scaled. The mixed methanol to catalyst was prepared in the prescribed ratio prior to be immersed into the reactor. The transesterification reaction took place at $60^{\circ} \mathrm{C}$. The yield of reaction was further determined based on the RSM tabulation.

\section{Experimental design}

Central composite rotatable design (CCRD) was used in the design expert software to evaluate three factors which were temperature, ratio of methanol to oil, and percentage of catalyst for esterification, but, for transesterification was molar ratio of methanol to oil, reaction time, and percentage of catalyst. There were five levels of point being analysed as shown in (Table 1 and 2). The response studied from the experiments was the final FFA content (esterification), and \% yield (transesterification).

\begin{tabular}{|l|c|c|c|c|c|}
\hline \multirow{2}{*}{ Factor } & \multicolumn{5}{|c|}{ Level } \\
\cline { 2 - 6 } & $\mathbf{- 1}$ & $\mathbf{- \alpha}$ & $\mathbf{0}$ & $\mathbf{+ \alpha}$ & $\mathbf{+ 1}$ \\
\hline Temperature $\left({ }^{\circ} \mathrm{C}\right)$ & 60 & 62.03 & 65 & 67.97 & 70 \\
\hline Ratio of methanol & 45 & 47.03 & 50 & 52.97 & 55 \\
\hline Number of catalyst (\%) & 0.4 & 0.48 & 0.6 & 0.72 & 0.8 \\
\hline
\end{tabular}

Table 1: Coded and actual levels of variable considered for design (esterification).

\begin{tabular}{|l|c|c|c|c|c|}
\hline \multirow{2}{*}{ Factor } & \multicolumn{5}{|c|}{ Level } \\
\cline { 2 - 6 } & $\mathbf{- 1}$ & $-\boldsymbol{\alpha}$ & $\mathbf{0}$ & $\mathbf{+ \alpha}$ & $\mathbf{+ 1}$ \\
\hline Molar ratio & 6.0 & 6.41 & 7.0 & 7.59 & 8.0 \\
\hline Reaction time (min) & 50 & 54.05 & 60 & 65.95 & 70 \\
\hline Catalyst amount (\%) & 0.8 & 0.84 & 0.9 & 0.96 & 1.0 \\
\hline
\end{tabular}

Table 2: Coded and actual levels of variable considered for design (transesterification).

\section{Results and Discussion}

Response surface methodology for optimization

A design expert for experiment of esterification with five levels and three factors (temperature, ratio of methanol, and amount of catalyst), and also experiment of transesterification with five levels and three factors (molar ratio, reaction time, and catalyst amount) was chosen. The experimental data obtained by above procedure was analysed by response surface methodology using following second degree polynomial model for both esterification and transesterification as shown in equation 1 and 2 .

$\mathrm{Y}_{1}=5.39-0.49 \mathrm{x}_{1}-0.54 \mathrm{x}_{2}-0.74 \mathrm{x}_{3}+0.53 \mathrm{x}_{1} \mathrm{x}_{2}+0.00375 \mathrm{x}_{1} \mathrm{x}_{3}-0.40 \mathrm{x}_{2} \mathrm{x}^{3}$

$-0.67 \mathrm{x}_{1}^{2}-0.077 \mathrm{x}_{2}^{2}-1.18 \mathrm{x}_{3}^{2}$

$\mathrm{Y}_{2}=75.5+0.85 \mathrm{x}_{1}^{\prime}+7.15 \mathrm{x}_{2}^{\prime}+7.30 \mathrm{x}_{3}^{\prime}+5.38 \mathrm{x}^{\prime}{ }_{1} \mathrm{x}_{2}{ }_{2}-2.37 \mathrm{x}_{1} \mathrm{x}_{3}^{\prime}+$ $4.38 x_{2}^{\prime} x_{3}^{\prime}-0.77 x^{\prime 2}{ }_{1}+1.18 x_{2}^{\prime 2}-0.77 x^{\prime 2}{ }_{3}$

The response for esterification was $Y_{1}$, and the response for transesterification was $Y_{2}$. The parameters involved in esterification such as temperature, ratio of methanol, and number of catalyst were indicated by $\mathrm{x}_{1}, \mathrm{x}_{2}$, and $\mathrm{x}_{3}$, respectively. While, $\mathrm{x}_{1}^{\prime}, \mathrm{x}_{2}^{\prime}$, and $\mathrm{x}_{3}^{\prime}$ denoted molar ratio, reaction time, and catalyst amount as the parameters involved in transesterification.

\section{Esterification}

The esterification was aimed to reduce the FFA content of waste oil. The optimization was used as the useful technique in making 
the research to be faster and more economical for grouping research results than full factorial experimentation or classical onevariable at a time [8]. In this study, the using of response surface methodology was to evaluate the corresponding three basic parameters such as temperature, ratio of methanol, and number of catalyst and also the interaction amongst of which in esterification of waste oil.

The response surface methodology of CCRD was chosen to optimise the whole involved parameters in this research study as shown in table 1 . The observed and predicted values of FFA in the treated waste oil at the designed points of different esterification condition are shown in figure 1 . Based on the analysis of variance (ANOVA), the models were analysed and appears to be adequate for observed data at level of $95 \%$ confidence and $p$ values were less than 5\%. As the resulted data are analysed using ANOVA, the model was founded significance as computed $\mathrm{F}$ value $\left(\mathrm{F}_{\text {Model }}=16.07\right)$ with very low probability value ( $\mathrm{P}$ value is $<0.0001$ ) indicates the very significant of fitted model with the value of $R^{2}$ is 0.94 . These results were comparable with another research due to showing the reliability of the regression model for predicting the FFA value of treated waste oil [9].

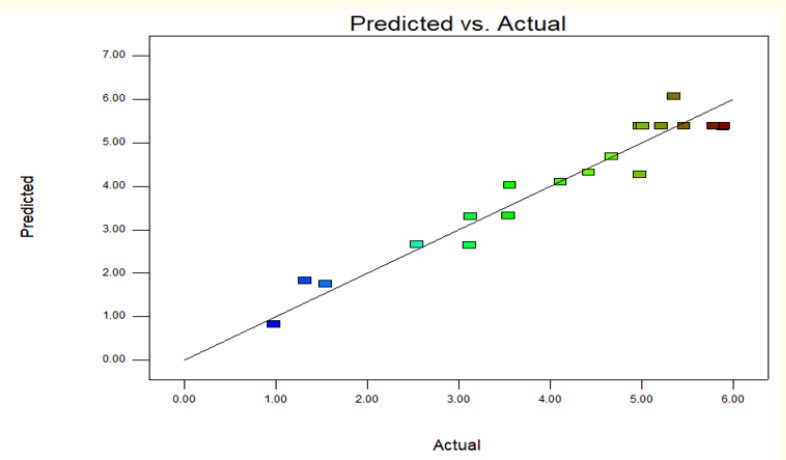

Figure 1: Plot of actual versus predicted value for esterification process.

The esterification process which involved the effects of temperature, catalyst amount, and ratio of methanol on the final content of FFA in the treated waste oil as shown in Figure 2 (a) and (b). The optimised esterification process was occurred at $65^{\circ} \mathrm{C}$ of temperature, $50 \% \mathrm{w} / \mathrm{w}$ of methanol ratio, and $0.80 \% \mathrm{w} / \mathrm{w}$ of catalyst amount with the lowest value of FFA in the esterified waste oil was 0.98. Opposite, at the other temperature, percentage of catalyst, and ratio of methanol, the final value of FFA was still higher than $1.0 \% \mathrm{w} / \mathrm{w}$ as shown in figure 2 . Such FFA values of treated waste oil were not suitable for using as feedstock of transesterification reaction.
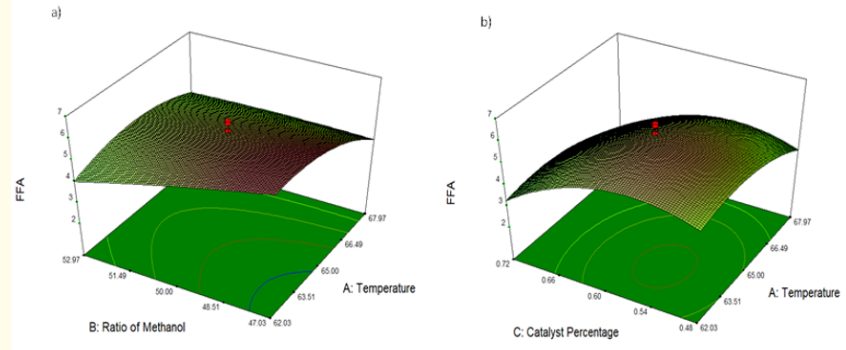

Figure 2: Final value of FFA in the esterified waste oil which was affected by a) temperature and methanol ratio, b) catalyst percentage and temperature.

\section{Transesterification}

In order to optimise the transesterification reaction, the response surface methodology of CCRD was also selected with few optimised parameters which were involved in this process as shown in table 2 . The model was highly significant as the probability value is lower ( $p$-value is less than 0.05). Based on the ANOVA results, the plot of predicted and actual value of reaction yield (Figure 3 ) indicated that the distribution of data was fitted and close to the diagonal line. This condition was supported by the value of $\mathrm{R}^{2}$ was 0.79 . Anyway, the interaction amongst the parameters was very significance. The phenomenon was indicated by the F-values in which such as the reaction time was 13.63 , the percentage of catalyst was 14.18. However, the F-value for parameter of molar ratio was smaller than other parameters, i.e. 0.19. This indicated that the effect of molar ratio was less significant in this process.

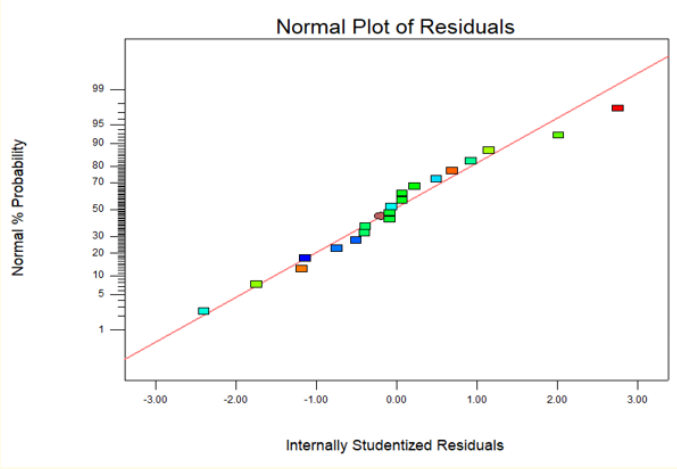

Figure 3: Plot of actual versus predicted value for transesterification process. 
Transesterification reaction under prescribed parameters such as molar ratio, amount of catalyst, and reaction time was carried out. Optimisation of transesterification process aims at resulting the simplification and economical. Figure 4 indicated the highest yield was obtained at 7 of molar ratio, $1.0 \%$ of catalyst percentage, and 60 minutes of reaction time. The optimal yield of transesterification reaction was achieved about $85 \%$. This study was also comparable with another work which stated that the overall conversion of oil to alkyl ester was determined on the basis of chromatogram peak area percentage [10].

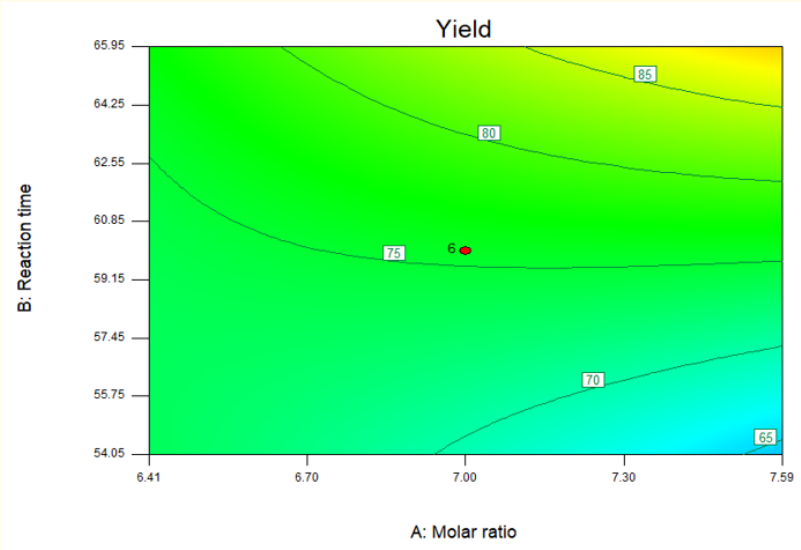

Figure 4: Contour graph of transesterification of treated waste oil.

\section{Conclusion}

The production of biodiesel from waste oil has been carried out through two chemical processes such as esterification and transesterification. The entire parameters which were involved in both processes are optimised by using response surface methodology. The esterification process was successfully to reduce the high concentration of waste oil FFA from $37.75 \%$ (initial content) becomes $0.98 \%$. The transesterification reaction was able to convert the waste oil to biodiesel until $85 \%$ of yield.

\section{Bibliography}

1. Singh SP and Dipti S. "Biodiesel production through the use of different sources and characterization of oil and their esters as the substitute of diesel: a review". Renewable and Sustainable Energy Reviews 14 (2010): 200-216.
2. Syam AM., et al. "Waste frying oil based-biodiesel: Process and Fuel properties". Smart Grid and Renewable Energy 4 (2013): 281-286.

3. Jung Y Hwang and J Bae C. "Assessment of particulate matter in exhaust gas for biodiesel and diesel under conventional and low temperature combustion in a compression ignition engine". Fuel 165 (2016): 413-424.

4. Kalebian-Kaikalaieh., et al. "A review on novel process of biodiesel production from waste cooking oil". Applied Engineering 104 (2013): 683-710.

5. Aransiola EF., et al. "Review of current technology for biodiesel production”. State Art Biomass Bioenergy 61 (2014): 276-297.

6. Hadavi SLi., et al. "Compression of gaseous emission for B100 and diesel fuels for real world urban and extra urban driving". SAE International Journal of Fuels and Lubricants 5 (2012): 1132-1140.

7. Anderson AP., et al. "Performance and emission evaluation in a power generator fuelled with Brazilian diesel and addition with waste frying oil biodiesel". Applied Thermal Engineering 98 (2016): 288-297.

8. Umer R., et al. "Application of response surface methodology for optimizing transesterification of moringa oleifera oil biodiesel production". Energy Conversion and Management 52 (2011): 3034-3040.

9. Lee KT., et al. "Optimum condition for preparation of flue gas desulfurization absorbent for rice husk ash". Fuel 84 (2005): 143-151.

10. Prakash CJ., et al. "Biodiesel production from mixture of mahua and simarouba oils with high free fatty acids". Biomass and Bioenergy 34 (2010): 1108-1116.

\section{Assets from publication with us}

- Prompt Acknowledgement after receiving the article

- Thorough Double blinded peer review

- Rapid Publication

- Issue of Publication Certificate

- High visibility of your Published work

Website: www.actascientific.com/

Submit Article: www.actascientific.com/submission.php Email us: editor@actascientific.com

Contact us: +919182824667 